\title{
Why are new journals created? An international analysis of Information and Documentation titles (2013-2018)
}

\author{
Cristóbal Urbano; Rosângela Schwarz Rodrigues; Marta Somoza-Fernández; Josep- \\ Manuel Rodríguez-Gairín
}

Nota: Este artículo se puede leer en español en:

http://www.elprofesionaldelainformacion.com/contenidos/2020/jul/urbano-rodrigues-somoza-rodriguez_es.pdf

How to cite this article:

Urbano, Cristóbal; Rodrigues, Rosângela Schwarz; Somoza-Fernández, Marta; Rodríguez-Gairín, Josep-Manuel (2020). "Why are new journals created? An international analysis of Information and Documentation titles (2013-2018)". Profesional de la información, v. 29, n. 4, e290413.

https://doi.org/10.3145/epi.2020.jul.13

Manuscript received on April $28^{\text {th }} 2020$ Accepted on June $08^{\text {th }} 2020$

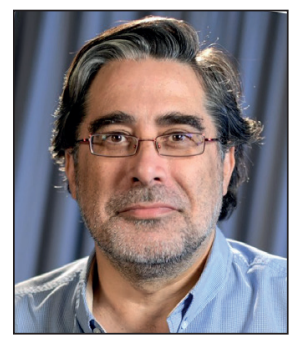

Cristóbal Urbano $\bowtie$

https://orcid.org/0000-0003-0935-6436

Universitat de Barcelona, Departament de Biblioteconomia, Documentació $i$ Comunicació Audiovisual

Melcior de Palau, 140

08014 Barcelona, Spain urbano@ub.edu

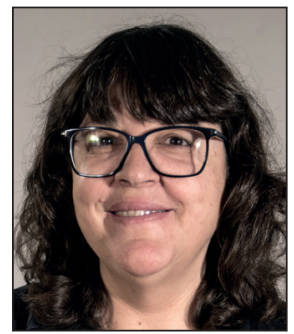
Marta Somoza-Fernández https://orcid.org/0000-0002-4769-9010
Universitat de Barcelona, Departament de Biblioteconomia, Documentació $i$ Comunicació Audiovisual Melcior de Palau, 140 08014 Barcelona, Spain msomoza@ub.edu

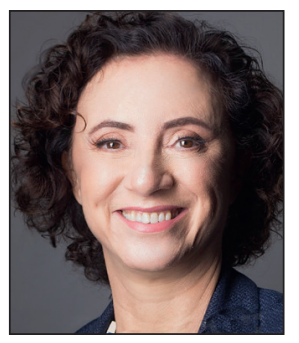

Rosângela Schwarz Rodrigues https://orcid.org/0000-0002-9639-6390

Universidade Federal de Santa Catarina, Programa de Pós-Graduação en Ciência da Informação.

Florianópolis, SC, Brazil.

rosangela.rodrigues@ufsc.br

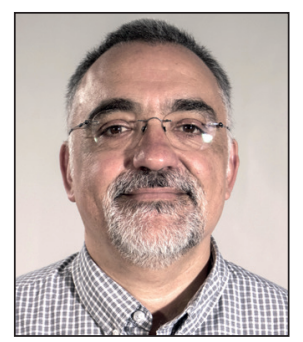

Josep-Manuel Rodríguez-Gairín https://orcid.org/0000-0001-8375-7911

Universitat de Barcelona, Departament de Biblioteconomia, Documentació $i$ Comunicació Audiovisual Melcior de Palau, 140 08014 Barcelona, Spain rodriguez.gairin@ub.edu

\begin{abstract}
The creation or title changes of scientific journals in the information and documentation (ID) area in the period 20132018 are analyzed. Based on the total of 62 such journals identified through ISSN Portal and Ulrichsweb, the following are described: characteristic aspects such as country, language, type of publisher, and access model; presence in bibliographic databases, citations, or journal directories; survival and volume of articles published; annual number of citations to articles according to Google Scholar; thematic scope declared by the editors; and finally, the justification given by the editors for the change of title or the creation of a new journal. Among the main conclusions regarding newly created titles, the leading role of academic publishers in expanding national university systems and open-access titles stands out. In general, new publications generate few articles per year, have little presence in databases, and receive few citations. Title changes were found only in journals published by commercial publishers. In both cases, journals with a general thematic scope predominate and a significant number of journals did not justify their creation or change of title.
\end{abstract}

\section{Keywords}

Information and Documentation; Documentation; Library and Information Science; Scholarly communication; Scientific journals; LIS; Creation of scientific journals; Publishers; Evaluation; Editorial management; Open access.

Funding

Rosangela Schwarz Rodrigues work in this paper was partialy founded by the Coordenação de Aperfeiçoamento de Nível Superior (Capes) Brazil. Finance code 001. 


\section{Introduction}

At the beginning of 2019 the full editorial board of the Journal of informetrics presented its resignation due to their disagreement with the limitations that Elsevier placed on open access to the bibliographic references of the journal, a policy that ignored the commitment of the members of the board to the Initiative for Open Citation (I4OC). As a result of this disagreement, the Quantitative science studies (QSS) journal was created, promoted by an editorial board formed from those who resigned from the Journal of informetrics (Singh-Chawla, 2019). The editors of the new publication did not argue the need to fill a gap, since the profile of the newly created title was similar to that of the previous title. In its blog, the International Society for Scientometrics and Informetrics (ISSI), the institution that promotes the new journal (Sugimoto, 2019), justified its commitment to open access as the main reason for the initiative to publish QSS, in clear contrast to the need to cover the communication needs in an emerging field given in 2007 by the editor of the Journal of informetrics (Egghe, 2007).

This example illustrates that numerous circumstances and motivations worthy of study converge in the creation of new journals. Explaining why a new journal is created can be considered both an obligation of its promoters and a field of study in itself within the framework of an ecosystem of scientific communication in which there is a debate on the number and profile of journals required to achieve optimal performance.

At the time of the creation or reorientation of a journal, the reasons that justify this initiative should be made clear in the publication itself through an article in the form of an editorial with an explanation of the circumstances, objectives, and scope of the publication; that is, its raison d'être. Along with this piece, the journal should include a detailed explanation of the nature of the publication on its website. In any case, beyond informing readers, the reasons given to justify the creation of a journal should provide the raw material for the decision-making process during its prenatal and perinatal period (Marušić; Marušić; King, 2013; Aparicio; Banzato; Liberatore, 2016; Smart, 2018).

The existence of such an explanation based on evidence and arguments, or the lack thereof, is an indicator of good practice. A Google search for the phrase "do we need a new journal" returns thousands of results, most corresponding to editorial pieces on the presentation of scientific journals that make a statement on their establishment in the first article of the new publication. ${ }^{1}$ This practice does not always occur on the launch of new publications, and even when it does, it does not always offer clear answers to the target audience, nor useful evidence for an external evaluator who wants to determine whether the journal should be included in a ranking system or indexed in a bibliographic database.

In any case, the phenomenon of journal creation deserves further studies to better understand the mechanisms underlying scientific communication systems. However, despite the abundant literature on scientific communication, few works have studied the reasons and motivations for journal creation. ${ }^{2}$ For this reason, this work presents a methodological exploration in this regard. The information and documentation (ID) ${ }^{3}$ area was chosen due its familiarity to the authors and its relatively small size in which the aforementioned exploration is more feasible.

Together with an analysis of various characteristics of the set of selected titles, we applied content analysis on the journal presentation texts to answer four research questions about the journals in the ID area that were created or changed their title between 2013 and 2018:

RQ1. What is the profile of the new journals and title changes?

RQ2. What are the characteristics of the journals in terms of their survival, volume of articles published, inclusion in databases, and citations received?

RQ3. What is the orientation of the journals in terms of the scope they give to the discipline, its methods, and its themes?

RQ4. How do their promoters justify the creation of new journals or the change of title of existing journals?

\section{Context}

The growth of scientific literature, and the proliferation of scientific journals in particular, has been a focus of study for many years, in terms of both general reflections (Bernal, 1939; Price, 1961; Ziman, 1980; Mabe; Amin, 2001; Chen et al., 2018) as well as from specific fields of knowledge (e.g., Baue, 2002). Broadly speaking, it can be said that the controversy over the growth of scientific journals has changed over time. From the end of World War II to the end of the 1980s, the proliferation of titles created or captured by commercial publishers was a controversial topic, in contrast to the more stable universe of the publications of scientific societies and academic institutions (Cox, 2002). From the end of the $20^{\text {th }}$ century until today, the focus has shifted towards the proliferation of open-access (OA) titles, whether promoted by institutions or commercially, as well as the so-called predatory journals (COPE Council, 2019).

Given this proliferation of titles, the decisive factor in evaluating the suitability of the creation of a journal is its ability to obtain recognition from the research community to which it is addressed, as well as to demonstrate that it is a necessary, useful, and viable project even before its appearance. Furthermore, the way in which the editors carry out this justification should be consistent with the very nature of scientific and academic knowledge, which, according to Cope and Kalantzis (2014, p. 11), must be systematic, premeditated, reflective, purposeful, disciplined, and open to scrutiny from a community of experts. 
The scientific journals that are recognized in a certain area achieve this as nodes in a network that itself assesses the rigor with which communication and knowledge preservation are facilitated. It is understood that the value of their published content is based on their reception and use by other researchers, through what has become known as the "Grand conversation" of science through space and time (Guédon, 2014). Thus, despite the claim that the evaluation of research must be substantiated by the intrinsic value of the articles in the context of an author's career (DORA, 2012; Hicks et al., 2015), and the emergence of more elaborate metrics in that direction (Van-Raan, 2019), it is still an established fact that researchers grant more or less recognition to some journals than others (Guédon, 2019).

This recognition has created an organized accreditation system in which the reputation of a publication acts as a proxy for the merit of the articles published therein. Typically, authors choose to send their original work to journals based on the quality and relevance of each title. The importance of a title has a lot to do with the number of readers and authors who communicate, or cite each other, via a well-placed journal in a given knowledge area (Ziman, 1980). This is why journals function as a system to organize an area of knowledge and, consequently, as a recognition mechanism, for both researchers and institutions, that aspire to achieve good standing in all kinds of academic and research rankings (Whitley, 1982; Kim et al., 2019).

The resulting set of publications with greater recognition, which is often called the scientific mainstream, is typically associated with the titles that appear in the impact rankings derived from the citation indexes of Clarivate's Web of Science or Elsevier's Scopus. In this way, the value that universities and governments give to the journals that are best positioned in this hierarchical system represents one of the most important factors determining the price of their subscriptions (Guédon, 2014) or the editorial services paid (article processing charge, APC) (Solomon; Björk, 2012; Björk; Solomon, 2015). Incorporating a new title into this system represents an immense challenge in terms of consolidation that requires, in successful cases, between two and seven years (Marušić; Marušić; King, 2013).

The growth in the number of titles in recent years (Johnson; Mabe; Mabe, 2018) indicates that this highly competitive context has not been an obstacle to the proliferation of new publishing projects. The basis for this response varies greatly depending on the nature of the publishers and their position within mainstream scientific communication. Therefore, it is important to distinguish three broad categories among the promoters of new journals, each made up of actors who adopt a different position in relation to questioning, or not, the status quo of established journals within the mainstream.

- In the first place, there are traditional commercial publishers, whose new initiatives aim to improve the representativeness of the set of journals that make up the mainstream and enhance their editorial offering to cover new market niches in emerging topics or respond to the demographic growth of the research community. This group includes most of the large commercial publishers, as well as university presses and scientific societies from the English-speaking world. Their ability to establish such new journals in the mainstream is facilitated by their past track record as publishers with significant accumulated symbolic capital.

- Secondly, we find academic institutions, scientific societies, and professional associations that publish journals, but for which neither is this activity their main business, nor do they have a publications division that operates in a fully commercial fashion. The editors working in this group have a critical position regarding the established scientific communication system. On the one hand, they point out the serious efficiency problems that prevent progress towards scientific communication conceived as a public good (Suber, 2009). On the other, they denounce the important failures in the representativeness of the global scientific community and the attention paid to cultural, linguistic, and geographic diversity (Chavarro; Tang; Ràfols, 2017). This reality is manifested in the small fraction of universities in the world whose journals are present in the WoS legacy citation indexes (Repiso; Orduña-Malea; Aguaded, 2019). In addition, they question the financing model of the system, since they argue that academia contributes by generating content and reviewing it but then pays significant sums for subscriptions, or APCs, to large publishing groups that represent an oligopoly in the system (Larivière; Haustein; Mongeon, 2015). In this context, editorial initiatives promoted by academia conceive the creation of journals as a lever to regain control of the publication system, promote its democratization according to the key concept of open science, or offer communication channels for scientific knowledge generated in peripheral countries (Meneghini, 2012).

- Thirdly and finally, it is worth considering commercial publishers that are natives of the digital environment. This is a group that has played a prominent role in the creation of new titles over the last 20 years, via an offering of OA journals with an APC business model (Binfield, 2014). This model has given rise to editorial projects that try to compete against traditional publishers, which are also currently open to the OA journal market. In this context, it is not easy to discriminate between reliable new actors in commercial OA publishing and so-called "predatory publishers," thus judgments on newly created titles are subject to debate based on the editorial guarantees that such new publishers must offer as well as the very definition of a predatory journal (Berger; Cirasella, 2015; COPE Council, 2019; Kratochvíl et al., 2020). In any case, it is clear that the business model adopted by this group has driven the appearance of many new journals in recent years, since the economic viability of these publishers is based on the economies of scale associated with the creation of either portals including titles from many fields of knowledge or general mega-journals containing thousands of articles per year.

In all three categories, the introduction of open access has constituted one of the most important factors marking the evolution of title creation or changes (Gu; Blackmore, 2016). The potential of the OA movement to transform the 
system of scientific publication (Willinsky; Moorhead, 2014) has crystallized as the share of OA articles in total scientific production, in both journals and repositories, has increased (Piwowar; Priem; Orr, 2019). Through this process, the creation of new OA journals has been one more driver of transformation and can thus be considered to be an explanatory factor for the creation of new titles in recent years.
The phenomenon of creating new journals is multifaceted and highly conditioned by the nature of the promoters and their position within mainstream scientific communication

If we focus attention on OA journals promoted by academia, it can be seen that their ability to become a real alternative to the commercial offering is far from fully satisfactory, since, in the words of Guédon (2014), this movement has resulted in

"a scattering of disconnected and uncoordinated efforts that testified to the need for new solutions, but with few means to bring them forward in a convincing way" (p. 97).

The effort required to address the increasing formal and technological demands set by standards (ISO 8, 2019; COPE Council, 2020), or the requirements of the directories' checklist for the selection of journals, as in the case of DOAJ, point to the need for professional technological and editorial support for journals that in many cases were created without such support. This reality, together with the lack of clear action in terms of public policies or institutional infrastructures to support open access, means that, in the ongoing transformation of the scientific publication system, commercial actors are setting the pace (Esposito, 2014; Velterop, 2018), by either introducing new fully OA titles or transforming subscription titles towards hybrid or fully open models (Crow; Gallagher; Naim, 2019).

\section{Materials and methods}

This work explores a methodology for the study of scientific communication, focusing on the phenomenon of the creation or title changes of journals during a period that one might call "perinatal." In light of this approach, the following objectives were formulated:

- To characterize online journals in the ID area that started (or underwent a change of title and ISSN) between 2013 and 2018 , according to their country, language, date, type of publisher, and access model.

- To analyze their presence in bibliographic databases or journal directories.

- To study their survival and annual volume of articles.

- To study their impact based on the number of citations they receive per year according to Google Scholar.

- To establish the thematic scope of journals as an expression of the scientific dynamics that publishers offer in the ID area.

- To typify how editors justify the creation of a journal or a change of title.

The six-year window used in this study ended in 2018 so that production and impact data from at least 2019 would be available. The titles were identified through ISSN Portal and Ulrichsweb:

https://portal.issn.org http://ulrichsweb.serialssolutions.com

The list of titles for analysis was formed from titles with DOls actively supplying metadata to Crossref. This filter was considered as a necessary (although not sufficient) condition for a standard scientific journal (ISO 8, 2019) that is open to automatic indexing. From the thematic point of view, the selection was limited to those that ISSN and UIrichs consider to be journals in the "library and information science" area.

First, a query to the ISSN Portal database (6 November 2019) resulted in 262 records of newly created publications and title changes, meeting the following conditions: type of resource, "Periodical"; start date, from 2013 to 2018; subject, records classified under the category "Science and knowledge > Librarianship"; and type of medium, "online." In a second stage and to address possible classification inconsistencies in ISSN Portal, a query was made to Ulrichsweb (12 December 2019) using the following criteria: subject headings, "Library and information sciences" and "Library and information sciences - Computer applications"; type of publication, "Journal," "Magazine," or "Bulletin"; format, "online"; and start date, from 2013 to 2018. This identified 19 records that had not been previously identified in the ISSN Portal librarianship thematic category, so these were also incorporated into the study once their data had been retrieved from the ISSN file.

In a third stage, those publications that presented the formal characteristics of a scientific journal were selected, without considering the quality of their content, as well as those that appeared in "Crossref" according to the "indexed" field of ISSN Portal. We also discarded: titles that were online versions of paper journals prior to 2013; titles that did not correspond to the ID scope and that were thus classification errors, or questionable classifications, in ISSN; those that were not journals, such as monographic series, bulletins, etc.; and, finally, journals with irrelevant title changes, being merely a variation of the name of the entity that previously appeared in the title. This third stage led to a list of 62 titles, all of them refereed journals according to the statement they make on their website. To enable a comparison with a previous equivalent period, this title identification process was repeated for the years 2007 to 2012.

See the data files on:

https://doi.org/10.6084/m9.figshare.12639692 
The information obtained from the ISSN file was completed by visiting the website of each journal, as well as other sources of information about the publishing institution or company to establish first-hand the type of publisher and the access features they offered (subscription versus OA, presence or absence of APC). To estimate the volume of articles published per year, the Crossref API was used on 2 February 2020. The analysis of their presence in indexing databases and in journal evaluation directories was carried out on 12 December 2019 using MIAR

http://miar.ub.edu

Finally, to obtain the number of citations according to Google Scholar, the Publish or Perish application was used to search by ISSN on 1 February 2020, narrowing down to articles published between 2013 and 2019.

https://harzing.com/resources/publish-or-perish

Once the records of each article had been retrieved, it was confirmed that all those that received citations actually corresponded to works from the analyzed journal, regardless of whether Google Scholar found the article on the journal's website, an aggregator portal, a repository, or an academic social network. Although such citation counts based on Google Scholar may present problems of normalization and accuracy, thanks to its wide coverage, it represents an effective option for the analysis of newly created journals, since the search engine conditions are homogeneous for all of them (Martín-Martín et al., 2018). As a limitation of this study, note that no data were collected on the volume of citations prior to the date of each title change. To study the influence of this type of transformation on the subsequent evolution of the impact indicators of the publications, a specific methodological design is required, which lies beyond the scope of this work.

To identify the reasons that each journal presented to justify its creation or change of title, content analysis (Neuendorf, 2002) of the journal presentation texts was carried out. This method has been used previously in works on the educational evolution of the ID area based on the analysis of teaching plans, study plans, and job offers (Chu, 2006), as well as in the study of the disciplinary and methodological framework of research based on publications of all kinds (Aharony, 2012; Tuomaala; Järvelin; Vakkari, 2014; Guallar et al., 2017). Our analysis was based on the texts present in the journals without resorting to external sources or direct contact with the editors. The value of the presentations lies in the fact that they are official statements issued by the editorial board.

We worked with a coding list for the inventory of possible motivations grouped into five areas: (1) thematic, disciplinary, or methodological; (2) audiences; (3) functional and editorial management; (4) related to cultural, linguistic, or historical-geographical specificities; and (5) related to public and institutional policies. See the data file on:

https://doi.org/10.6084/m9.figshare.12639692

This was prepared based on an initial analysis of the journals studied and compared with the motivations identified in literature. In this regard, similar studies were considered (Rowland, 1981) as well as testimonies and experiences of editors, or case studies of specific journals (Bailey, 1989; Haynes, 1999; Regier, 2005; Binfield et al., 2008; Coulter, 2010; Lyons, 2011; Johnson; Putnam-Davis; Bandy, 2019), and manuals or guidelines for editors (Stranack, 2008; Marušić; Marušić; King, 2013; Smart, 2018). The content analysis was carried out simultaneously and based on consensus between two encoders, so no reliability test had to be performed between them. For journals in languages other than English, Spanish, and Portuguese, English versions of the editorial texts were used whenever available; in other cases, Google Translate was used.

To classify the journals by subject, classifications previously used in content analyses carried out in the ID area were studied (Zins, 2007; Aharony, 2012; Guallar et al., 2017), but it was considered that the development of an ad hoc classification with two facets was more effective for the purposes of this study. To classify the journals according to their subject scope and their orientation towards a specific type of information unit, such as archives, libraries, etc., what we call "thematic lines" and "application environments" facets were applied (Table 6).

\section{Results and Discussion}

\subsection{Characterization of the journals}

\subsubsection{Distribution by year}

Between 2013 and 2018, 12 title changes were recorded, compared with 10 in the previous six years. Fifty cases of newly created journals were identified, compared with 58 in the previous period (2007-2012), representing a decrease of $16.7 \%$. In any case, the joint trend for the 12 years revealed a slight upward line, indicating a stabilized situation (Graph 1).

\subsubsection{Distribution by country}

The 12 title changes occurred in three countries (10 in the UK, 1 in the USA, and 1 in Germany): these corresponded to journals from commercial publishers, or titles they managed on behalf of professional associations (Table 1). They included a single merger and no splits. Among the 50 newly created titles, the USA (12) was most prominent, followed by India (8), Indonesia (8), and Brazil (5), three emerging countries with large populations and expanding university systems, where the pressure to publish among new faculty in the studied area could explain the higher volume of new editorial projects. Countries that are considered to be peripheral with respect to the traditional North American and Western Europe mainstream thus stand out regarding the creation of new journals. The sum of titles from the USA, Canada, 
and Western Europe represented $36 \%$ of the total, while the rest of the world generated $64 \%$. There was a wide distribution across continents, diluting the traditional dominance of the USA and Europe in the editorial dynamics of the ID area.

A comparison of the list of countries between the two chronological ranges reveals that, in the last six years (2013-2018), the distribution between countries was narrower, European countries were less prominent, and the number of titles from Indonesia has grown a lot. In both periods, the absence of journals from China is notable, although this country occupies the third position worldwide in terms of volume of works in the ID area according to the SCImago Country Rank for the period 1996-2018, but it has not channeled these through new journals of its own, whose creation is subject to a complex process of government authorization. https://www.scimagojr.com/countryrank.php?category=3309

In the words of Lin (2013), this system gives the last word to the government, which acts in a very restrictive way based on the justification that journals are part of the planned economy. This limitation explains why certain initiatives to launch new titles by Chinese academics end up being published in collaboration with foreign actors and from other countries while, at the same time, the number of Chinese authors in journals that are well positioned in terms of impact indexes is clearly growing, strengthening the domination of the English-speaking mainstream.

Table 1 . Titles by country

\begin{tabular}{|c|c|c|c|c|c|}
\hline \multicolumn{3}{|c|}{$\begin{array}{c}2007-2012 \\
N=68[58+(10)]\end{array}$} & \multicolumn{3}{|c|}{$\begin{array}{c}2013-2018 \\
N=62[50+(12)]\end{array}$} \\
\hline & $\mathbf{n}$ & $\%$ & & $\mathbf{n}$ & $\%$ \\
\hline USA $^{*}$ & $16+(4)$ & 29.4 & USA* & $12+(1)$ & 21.0 \\
\hline India & 12 & 17.6 & $\mathrm{UK}^{*}$ & $1+(10)$ & 17.7 \\
\hline Brazil & 7 & 10.3 & India & 8 & 12.9 \\
\hline $\mathrm{UK}^{*}$ & $1+(2)$ & 4.4 & Indonesia & 8 & 12.9 \\
\hline Denmark* $^{*}$ & $(2)$ & 2.9 & Brazil & 5 & 8.1 \\
\hline Nigeria & 2 & 2.9 & Canada & 4 & 6.5 \\
\hline Norway & 2 & 2.9 & Mexico & 2 & 3.2 \\
\hline Poland & 2 & 2.9 & Turkey & 2 & 3.2 \\
\hline United Arab Emirates & 2 & 2.9 & Ukraine & 2 & 3.2 \\
\hline Belgium & 1 & 1.5 & Belgium & 1 & 1.6 \\
\hline Costa Rica & 1 & 1.5 & Germany* & (1) & 1.6 \\
\hline Croatia & 1 & 1.5 & Jordan & 1 & 1.6 \\
\hline Czech Republic & 1 & 1.5 & South Korea & 1 & 1.6 \\
\hline Finland* & (1) & 1.5 & Poland & 1 & 1.6 \\
\hline France & 1 & 1.5 & Qatar & 1 & 1.6 \\
\hline Germany* & (1) & 1.5 & Russia & 1 & 1.6 \\
\hline
\end{tabular}

\begin{tabular}{|l|l|l|}
\hline Indonesia & 1 & 1.5 \\
\hline Japan & 1 & 1.5 \\
\hline South Korea & 1 & 1.5 \\
\hline Qatar & 1 & 1.5 \\
\hline Russia & 1 & 1.5 \\
\hline Serbia & 1 & 1.5 \\
\hline Spain & 1 & 1.5 \\
\hline Switzerland & 1 & 1.5 \\
\hline Uruguay & 1 & 1.5 \\
\hline
\end{tabular}

* Countries for which title changes/mergers are indicated in parentheses 


\subsubsection{Distribution by language}

Among the languages of the publications (Table 2), English predominates, since the titles that declare it as a single language (39) plus those that explicitly consider it together with other languages (3) sum to a total of 42 titles (67.74\%) that accept articles in this language, and one could even add more from among those that include the generic mention of "multiple languages" in their ISSN file. Only the 7 journals that publish in Indonesian and the 5 Brazilian ones that do so in Portuguese mitigate this dominance of English. In both cases, it is assumed that the creation of new titles serves to provide the opportunity to publish works in the native language of institutions of countries that are emerging in terms of both the number of faculty and centers in the ID area, as occurred in the past with the creation of ID journals in Spain (Delgado-López-Cózar, 2001). In the case of India, the other country with great prominence in the analyzed period, and also a growing university system, all of them mention only English as a language.
Table 2. Languages of the publications

\begin{tabular}{|l|c|c|}
\hline \multirow{2}{*}{\multicolumn{1}{|c|}{ Language }} & \multicolumn{2}{c|}{$\begin{array}{c}\text { Journals } \\
\text { N=62 }\end{array}$} \\
\cline { 2 - 3 } English* & $\mathbf{n}$ & $\%$ \\
\hline Indonesian & $27+(12)$ & 62.9 \\
\hline Multiple languages & 7 & 11.4 \\
\hline Portuguese & 6 & 9.7 \\
\hline Spanish & 4 & 6.5 \\
\hline Portuguese, English, Spanish & 2 & 3.2 \\
\hline Arabic, English & 1 & 1.6 \\
\hline Russian & 1 & 1.6 \\
\hline English, French & 1 & 1.6 \\
\hline
\end{tabular}

* Languages for which title changes/mergers are indicated in parentheses

\subsubsection{Publishing entities and type of access}

The editorial dynamics in terms of the type of publisher and business model varied greatly by country (Tables 3 and 4 ). It is interesting to observe that commercial publishing only has a presence in 5 of the 16 countries analyzed, corresponding to a minimally relevant volume in three of these: the USA, the UK, and India. Poland and Germany each have a single title in the study.

The predominance of institutional, academic, or association publishing is almost complete in the rest of the countries, standing out in terms of volume in the case of the journals from Indonesia, Brazil, or Canada, which all come from an institutional context (universities, research institutes, scientific societies, or professional associations). Two cases were placed under the heading of "Individuals," viz. a Mexican journal from a one-man publisher and an American journal promoted by a group without an identified institutional link.

Notable differences were found between the prevalence of classic commercial publishers with subscription/hybrid offerings in the case of the UK, compared with the case of India, where all the publishing is commercial and linked to numerous recently created titles. Overall, open-access titles represented the majority $(74.2 \%$ if one includes those that charge an APC and those that do not), as did the use of the Open Journal Systems (OJS) program of the Public Knowledge Project (PKP); indeed, 28 journals (60.9\%) among all the OA titles use this program individually or are hosted on a portal managed by the OJS. The rest of the non-OA journals are split between hybrid (17.7\%) and subscription models (8.1\%).

Table 3. Publisher type by country

\begin{tabular}{|c|c|c|c|c|c|}
\hline \multirow{2}{*}{$\mathrm{N}=62$} & Total & $\begin{array}{l}\text { University/re- } \\
\text { search institute }\end{array}$ & $\begin{array}{c}\text { Scientific society/ } \\
\text { professional } \\
\text { Association }\end{array}$ & $\begin{array}{c}\text { Commercial } \\
\text { publisher }\end{array}$ & Individuals \\
\hline & $\begin{array}{c}50+(12) \\
100 \%\end{array}$ & $\begin{array}{c}24 \\
38.7 \%\end{array}$ & $\begin{array}{c}10 \\
16.1 \%\end{array}$ & $\begin{array}{c}14+(12) \\
41.9 \%\end{array}$ & $\begin{array}{c}2 \\
3.2 \%\end{array}$ \\
\hline USA* & $12+(1)$ & 3 & 3 & $5+(1)$ & 1 \\
\hline $\mathrm{UK}^{*}$ & $1+(10)$ & & 1 & (10) & \\
\hline Indonesia & 8 & 8 & & & \\
\hline India & 8 & & & 8 & \\
\hline Brazil & 5 & 5 & & & \\
\hline Canada & 4 & 1 & 3 & & \\
\hline Other countries with 1 or 2 titles* & $12+(1)$ & 7 & 3 & $1+(1)$ & 1 \\
\hline
\end{tabular}

* Countries for which title changes/mergers are indicated in parentheses
The creation of new titles serves to provide a vehicle for work in the language of institutions in emerging countries 
Table 4. Types of access by country

\begin{tabular}{|c|c|c|c|c|c|}
\hline & Total & Only subscription & Hybrid & OA without APC & OA with APC \\
\hline $\mathrm{N}=62$ & $\begin{array}{c}50+(12) \\
100 \%\end{array}$ & $\begin{array}{l}4+(1) \\
8.1 \%\end{array}$ & $\begin{array}{c}(11) \\
17.7 \%\end{array}$ & $\begin{array}{c}35 \\
56.5 \%\end{array}$ & $\begin{array}{c}11 \\
17.7 \%\end{array}$ \\
\hline US* & $12+(1)$ & 1 & $(1)$ & 7 & 4 \\
\hline $\mathrm{UK}^{*}$ & $1+(10)$ & (1) & (9) & 1 & \\
\hline Indonesia & 8 & & & 7 & 1 \\
\hline India & 8 & 3 & & & 5 \\
\hline Brazil & 5 & & & 5 & \\
\hline Canada & 4 & & & 4 & \\
\hline Other countries with 1 or 2 titles* & $12+(1)$ & & (1) & 11 & 1 \\
\hline
\end{tabular}

* Countries for which title changes/mergers are indicated in parentheses

\subsection{Inclusion in indexing databases and directories}

The 12 publications resulting from changes or mergers of titles have a higher presence in databases than the newly created ones. They all appear in the Ulrichsweb directory as peer-reviewed scientific journals. There is only one case of change of title for which no presence has been identified in the databases and directories controlled by MIAR. The remaining 11 are indexed in various specialized or multidisciplinary databases (on average being present in 4.6 databases). Finally, all of them are present in Scopus (11 cases) or WoS (4 cases in AHCl, SSCl, or SCIE and 6 in ESCI). The history under the previous title and the link to traditional commercial publishers (De Gruyter, Emerald, and Taylor and Francis) explain this reality.

Focusing on the 50 newly created titles, it is observed that most of the publications are not present in databases or journal directories. Only 29 titles (58.0\%) appear in the Ulrichsweb directory; none are listed in WoS, and only one in Scopus; only two in Lista, the only database specialized in ID of those analyzed in the MIAR matrix that includes some of the new journals; 7 (14.0\%) appear in multidisciplinary or specialized databases in other thematic areas, all of them published in English, or in multiple languages including English. The finer-grained analysis of the journals that appear in DOAJ is important (Table 5), since $92 \%$ of the newly created journals are OA, but the presence in that directory is not homogeneous among the different types of publishers or OA models. Only 21 titles $(45.7 \%)$ overcome the entry barrier to DOAJ, and only 3 of them have the "DOAJ Seal," which is awarded to journals that exceed editorial quality standards and additional good practices.

Table 5. Newly created OA journals present in DOAJ by type of publisher and economic model

\begin{tabular}{|c|c|c|c|c|c|c|c|}
\hline \multirow{2}{*}{\multicolumn{2}{|c|}{$N=46$}} & $\begin{array}{l}\text { All OA } \\
\text { journals }\end{array}$ & In DOAJ & $\begin{array}{c}\text { Journals } \\
\text { without } \\
\text { APC }\end{array}$ & $\begin{array}{c}\text { Without } \\
\text { APC in } \\
\text { DOAJ }\end{array}$ & $\begin{array}{l}\text { OA journals } \\
\text { with APC }\end{array}$ & $\begin{array}{c}\text { With APC in } \\
\text { DOAJ }\end{array}$ \\
\hline & & $\begin{array}{c}46 \\
100 \%\end{array}$ & $\begin{array}{c}21 \\
45.7 \%\end{array}$ & 35 & $\begin{array}{c}19 \\
41.3 \%\end{array}$ & 11 & $\begin{array}{c}2 \\
4.3 \%\end{array}$ \\
\hline \multirow{2}{*}{ Institutional } & University/research institute & $\begin{array}{c}24 \\
100 \%\end{array}$ & $\begin{array}{c}15 \\
62.5 \%\end{array}$ & 23 & $\begin{array}{c}14 \\
58.3 \%\end{array}$ & 1 & $\begin{array}{c}1 \\
4.2 \%\end{array}$ \\
\hline & $\begin{array}{l}\text { Scientific society/ } \\
\text { professional association }\end{array}$ & $\begin{array}{c}9 \\
100 \%\end{array}$ & $\begin{array}{c}5 \\
55.6 \% \\
\end{array}$ & 9 & $\begin{array}{c}5 \\
55.6 \% \\
\end{array}$ & 0 & $\mathrm{n} / \mathrm{a}$ \\
\hline \multirow{2}{*}{ Noninstitutional } & Commercial publisher & $\begin{array}{c}11 \\
100 \%\end{array}$ & $\begin{array}{c}1 \\
9.1 \%\end{array}$ & 1 & $\begin{array}{c}0 \\
0 \%\end{array}$ & 10 & $\begin{array}{c}1 \\
9.1 \%\end{array}$ \\
\hline & Individuals & $\begin{array}{c}2 \\
100 \%\end{array}$ & $\begin{array}{c}0 \\
0 \%\end{array}$ & 2 & $\begin{array}{c}0 \\
0 \%\end{array}$ & 0 & $\mathrm{n} / \mathrm{a}$ \\
\hline
\end{tabular}

The journals linked to academic or professional institutions represent the majority among those that appear in DOAJ, corresponding to 15 of the 21 titles present, while only 1 of the 13 titles from commercial publishers and individuals and only 2 of the 11 with APC appear. The only OA journal from a commercial publisher listed in DOAJ corresponds to a traditional publisher (De Gruyter). These data for the commercial OA journals, together with their almost complete absence from other abstracting and indexing databases, indicates the existence of a good number of titles about which one might have serious reservations.

If we look at their date of creation, this observation of low presence in indexing databases, or in DOAJ, remains quite uniform through time. Although a slight advantage might be assumed for older journals, there is no clear trend in this regard in the percentage of journals indexed or with a presence in DOAJ among those created each year: $45.5 \%$ (5 of 11) in $2013,50.0 \%$ (3 of 6) in 2014, 33.3\% (2 of 6) in 2015, $45.5 \%$ (5 of 11) in 2016, $50.0 \%$ (3 of 6) in 2017, and $60.0 \%$ (6 out of 10) in 2018. 


\subsection{Survival and production volume in Crossref}

All the journals resulting from title changes or mergers remained active in 2019. Their article production volume is much higher than that of newly created ones: the 12 journals considered contained a median of 33 articles per year, an average of 44 , while a single title published fewer than 10 articles per year.

Among the 50 newly created journals, only 3 of them showed no activity in 2019, or earlier. However, the fact that the majority of journals are active does not mean that this activity is relevant in all cases, or that it has been correctly communicated to Crossref. Thus, of the 47 newly created journals that were active in 2019, 27 did not communicate metadata to Crossref for some of the publication years: 21 did so within a few years of their appearance, and 10 show empty years after their registration in Crossref was activated. This irregular coverage indicates editorial management weakness for a good number of titles. In any case, despite these limitations, the number of articles published according to the data from the years reported to Crossref may indicate the existence and vitality of the newly created titles (Table 6).

Table 6. Articles in newly created journals circulating per year in Crossref

\begin{tabular}{|c|c|c|c|c|c|}
\hline \multicolumn{2}{|l|}{$\mathbf{N}=\mathbf{5 0}$} & \multirow{2}{*}{$\begin{array}{c}\text { All journals } \\
50 \\
\end{array}$} & \multirow{2}{*}{$\begin{array}{c}\text { Articles per year } \\
\text { (median) }\end{array}$} & \multirow{2}{*}{$\begin{array}{c}\text { Articles per year } \\
\text { (average) }\end{array}$} & \multirow{2}{*}{$\begin{array}{c}\text { \% of journals with } \\
\text { fewer than } 10 \text { arti- } \\
\text { cles per year } \\
28.0\end{array}$} \\
\hline \multirow{5}{*}{ Publisher } & & & & & \\
\hline & University/research institute & 24 & 16 & 16 & 12.5 \\
\hline & Scientific society/professional association & 10 & 18 & 16 & 20.0 \\
\hline & Commercial publisher & 14 & 10 & 11 & 50.0 \\
\hline & Individuals & 2 & $\mathrm{n} / \mathrm{a}$ & $\mathrm{n} / \mathrm{a}$ & 50.0 \\
\hline \multirow{3}{*}{ Access } & OA without APC & 35 & 16 & 16 & 20.0 \\
\hline & OA with APC & 11 & 9 & 11 & 54.5 \\
\hline & Not OA & 4 & 16 & 15 & 25.0 \\
\hline
\end{tabular}

Newly created commercial journals, corresponding to $50.0 \%$ of the titles with fewer than 10 articles per year, as well as OA journals operating under the APC model with 54.5\%, have levels of articles per year lower than new titles driven by academia or professional associations. This finding coincides with their lower recognition in databases or journal directories: none of the 7 newly created commercial journals with an average of fewer than 10 articles per year were present in DOAJ or in the databases with international coverage used herein, despite the fact that many of them proclaim on their websites that they are indexed by a wide range of sites.

\subsection{Impact. Citations per year}

Although Google Scholar as a source of citations and the indicator used have their limitations, the method allows an assessment of the extent to which newly created journals are relevant, at least, to their tight target audience, beyond the citations they may receive from international mainstream journals. Google Scholar allowed an assessment of the profile of citations from all kinds of academic sources, such as master's or doctorate theses, reports, repositories, or national journals including the analyzed journal itself, since self-citations were not discarded. Table 7 shows that the journal set receives few citations (a median of 7.7 citations and a mean of 10.9 per year), with $54 \%$ of titles receiving fewer than 10 citations per year. These data are very revealing, since they demonstrate a fundamental barrier to the consideration of these journals as recognized instruments for scientific communication. Now, within this panorama of very low impact in general, it is the journals published by scientific societies or associations that present the best figures: a median of 11.1 citations per year, an average of 12.1, and only $30 \%$ with fewer than 10 citations.

Table 7. Citations per year among the newly created journals

\begin{tabular}{|c|c|c|c|c|}
\hline $\mathrm{N}=\mathbf{5 0}$ & All journals & $\begin{array}{c}\text { Citations per year } \\
\text { (median) }\end{array}$ & $\begin{array}{c}\text { Citations per year } \\
\text { (average) }\end{array}$ & $\begin{array}{l}\% \text { of journals with } \\
\text { fewer than } 10 \text { cita- } \\
\text { tions per year }\end{array}$ \\
\hline New titles & 50 & 7.7 & 10.9 & 54,0 \\
\hline University/research institute & 24 & 7.4 & 11.7 & 58.3 \\
\hline Scientific society/professional association & 10 & 11.1 & 12.1 & 30.0 \\
\hline Commercial publisher & 14 & 5.1 & 10.0 & 57.1 \\
\hline Individual & 2 & $\mathrm{n} / \mathrm{a}$ & $\mathrm{n} / \mathrm{a}$ & 100 \\
\hline
\end{tabular}

In contrast, as might be expected based on their longer history, good presence in bibliographic databases, and greater number of articles published per year, the journals corresponding to title changes have a greater impact: all having more than 10 citations per year, with a median of 50.6 and an average of 93.7. 


\subsection{Findings according to the thematic scope of the journals}

Among the 50 newly created titles (Table 8), 32 (64\%) were identified as having a general profile for the two facets considered. This profile corresponds to the traditional difficulty in the ID area over time regarding the specialization of journals along specific lines, largely due to the reduced number of authors globally and the territorial fragmentation of the research communities. However, one could say that this breadth of themes and approaches has been reinforced in recent years by an opening up that has diluted disciplinary borders. Beyond a natural tendency towards multidisciplinarity in journals in the ID area, considering the insufficiency of the arguments observed in the content analysis, this would be an editorial strategy that aims to accommodate a wide variety of articles as long as they are related to the topic of information in a broad sense, whether by authors from the world of communication, documentation, other social sciences, or information and communication technologies, a trend that was already observed in recent years (Chang, 2018; Urbano; Ardanuy, 2020).

Table 8. Newly created journals by thematic scope: thematic lines versus application environments

\begin{tabular}{|c|c|c|c|c|c|c|}
\hline $\begin{array}{l}\mathbf{N}=\mathbf{5 0} * \\
\text { * Some journals may be classified in more than one thematic line }\end{array}$ & 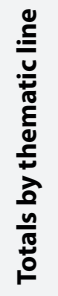 & 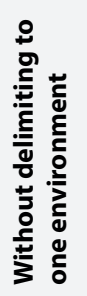 & 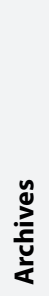 & 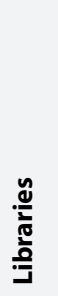 & 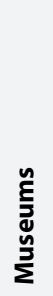 & 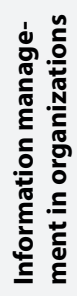 \\
\hline Totals by application environment & 50 & 38 & 2 & 8 & 1 & 2 \\
\hline 0. General & 41 & 32 & 2 & 5 & 1 & 1 \\
\hline 1. Organization and management of information units & 0 & & & & & \\
\hline 2. Documentary technical processes; representation and retrieval of information & 1 & 1 & & & & \\
\hline 3. Information resources, holdings, and collections & 0 & & & & & \\
\hline 4. Technological resources; information and communication technologies & 1 & & & & & 1 \\
\hline 5. Use and users of information; informational behavior & 1 & & & 1 & & \\
\hline $\begin{array}{l}\text { 6. Publishing and communication ecosystems; metrics for and evaluation of scientific } \\
\text { communication }\end{array}$ & 1 & 1 & & & & \\
\hline 7. Social, political, and cultural framework of information & 2 & 1 & & 1 & & \\
\hline 8. Theory, research, methods, and professional training & 1 & 1 & & & & \\
\hline 9. History of the discipline; documentary history and heritage & 3 & 2 & & 1 & & \\
\hline
\end{tabular}

The lack of a specialized profile for most journals, which in some cases could be attributed to a strategic commitment (epistemological or editorial management), in most cases is not justified in the analyzed texts. As seen later from Table 10 , only 14 journals $(28.0 \%)$ justify their creation from the point of view of their thematic, methodological, or disciplinary scope. In addition, it must be borne in mind that $60.0 \%$ of the journals only explain their scope using a set of inconsistently presented descriptors, without a logic to explain why some appear rather than others based on their level of specificity, since they appear as examples of topics to be covered rather than as a defining list. In this section, only in 16 cases (32.0\%), together with the descriptors, is an argument given regarding the scope of the journal, allowing a glimpse of some sort of epistemological or methodological vision regarding the thematic lines on which the journal wishes to focus. This finding, together with the fact that only 23 journals (46.0\%) include an editorial presentation article in their first issue (Table 10), makes it difficult to present a portrait of the vision of the ID area of the editorial teams that launched new titles in the analyzed period.

The situation of the 12 journals that changed title is not very different, since we see that general titles also dominate, 7 being so for both facets considered, 1 in terms of the "application environment" facet, and 4 presenting a focus on one of the "thematic lines" but without being limited to an "application environment." It should be noted that all the titles that we have classified as generalist are the result of commercial publishers' commitment to broaden their thematic scope with respect to the previous stage, or to make them more attractive to an audience far from the terminological culture of the ID area (Table 9). In the remaining 5 cases, their specialized focus was maintained, and in no cases was there greater specialization with respect to the previous title, indeed rather the opposite.

The low level of citations that newly created journals receive indicates the difficulty they face in being recognized as relevant even in their own national environment 
Table 9. Official title of journals resulting from title changes or mergers

\begin{tabular}{|l|l|}
\hline Current title & Previous title \\
\hline Archives and records & Journal of the Society of Archivists \\
\hline Aslib journal of information management & Aslib proceedings \\
\hline Collection and curation & Collection building \\
\hline Data technologies and applications & Program \\
\hline Digital library perspectives & OCLC systems \& services \\
\hline Global knowledge, memory and communication & Library review \\
\hline Information and learning science & New library world \\
\hline Information discovery and delivery & Interlending \& document supply \\
\hline International journal of library and information services & International journal of digital library systems \\
\hline Journal of the Australian Library and Information Association & Australian library journal + Australian academic and research libraries \\
\hline Preservation, digital technology \& culture & Microform \& digitization review \\
\hline VINE journal of information and knowledge management systems & VINE \\
\hline
\end{tabular}

The title changes serve to reflect an expansion of the thematic scope; expand the range of resources, technologies, and processes covered, avoiding the mention of those that have fallen into disuse; or avoid a dependence on a specific type of information unit, in most cases to avoid falling into the pigeonhole of the library environment. Among the most radical cases of this transformation are Global knowledge, memory, and communication and Information and learning science, which emerged from two titles in which the word "library" was central to the title. Among the titles with a specialized focus but a broader application environment, an example is provided by Collection and curation, which is open to all kinds of collections and special collections that form part of a heritage, not only from the library environment as happened in the origin of this journal.

In most cases, the commercial publishers who made the title changes do not justify the transformation of their journal as a response to new disciplinary, epistemological, or methodological dynamics. Rather, they accept the positioning risk that a change of title entails -considering that the title summarizes the brand value of the publication-in order to overcome the lack of attractiveness of the previous title to readers and authors from other areas. In an increasingly competitive environment in which journals strive to attract the greatest number of high-quality manuscripts, this commitment to a much wider community of authors than the traditional one in the ID area is both a reaction to the transformation of the disciplinary, epistemological, and methodological framework and an editorial strategy to generate a greater number of citations, which facilitates their positioning in the rankings.

Among all 62 journals analyzed, it is noted that no titles appear in some of the traditional thematic lines that make up the teaching and research core of the field. The specialization of journals within the ID area has traditionally been considered a sign of maturity (Delgado-López-Cózar, 2001), so it is worth asking whether the current process of digital transformation of the ID area, in which the proliferation of more general titles is again observed even more so than a few years ago, is a sign of immaturity or of the dissolution of the area into broader epistemological frameworks. Many authors claim that the existence of journals dedicated to an area is a key element of academic identity creation for a community of researchers (Hartley et al., 2019). Taking this argument to the limit, we could point out that the opening of journals to content beyond the ID area is a manifestation of the blurring of their disciplinary identity in the digital context, a reality to which publishers have paid attention (Ollé-Castellà; López-Borrull; Abadal, 2016). This trend that has been observed in journals is also consistent with the transformation of traditional educational institutions in the area, as evidenced by the high penetration of the iSchool movement, even in American universities that offer programs accredited by the American Library Association.

\subsection{Justification for the creation or title change of journals}

\subsubsection{Newly created titles}

Most of these 50 journals offer an undetailed if any justification. In any case, significant differences can be observed depending on the type of publisher and the access model (Table 10). Among the journals created by academic or professional institutions, the journals that are linked to scientific societies or professional associations justify their creation more than university journals, probably as a result of a need to reach agreements between people from various universities or institutions. In fact, this would be the best type of publisher to act as a combining and coordinating element for the individual publishing initiatives of universities and research centers in order to avoid overlap, duplication, and sterile competition between them. In any case, the collection of publishers that we have considered to be institutional, and which also includes universities, performs better than noninstitutional ones from the point of view of the clarity with which they justify and document their creation, whereas commercial journals operating under the OA model with APC are especially deficient in this regard. 
Table 10. Evidence on the justification for the creation of new journals according to type of publisher and access model

\begin{tabular}{|c|c|c|c|c|c|c|c|}
\hline \multirow{2}{*}{\multicolumn{2}{|c|}{$\mathrm{N}=\mathbf{5 0}$}} & 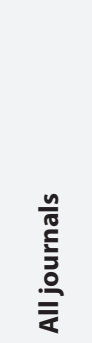 & 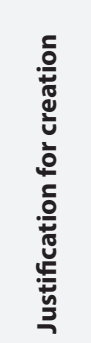 & 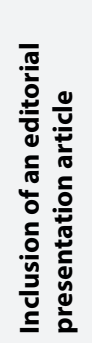 & 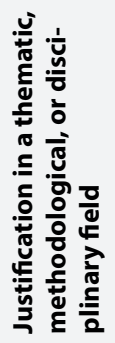 & 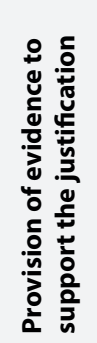 & 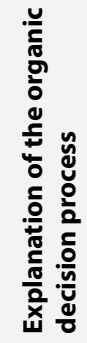 \\
\hline & & $\begin{array}{c}50 \\
100 \%\end{array}$ & $\begin{array}{c}34 \\
68.0 \%\end{array}$ & $\begin{array}{c}23 \\
46.0 \%\end{array}$ & $\begin{array}{c}14 \\
28.0 \%\end{array}$ & $\begin{array}{c}5 \\
10 \%\end{array}$ & $\begin{array}{c}6 \\
12.0 \%\end{array}$ \\
\hline \multirow{2}{*}{$\begin{array}{l}\text { Institutional } \\
\text { publisher }\end{array}$} & University/research institute & $\begin{array}{c}24 \\
100 \%\end{array}$ & $\begin{array}{c}19 \\
79.2 \%\end{array}$ & $\begin{array}{c}11 \\
45.8 \%\end{array}$ & $\begin{array}{c}5 \\
20.8 \%\end{array}$ & $\begin{array}{c}1 \\
4.2 \%\end{array}$ & $\begin{array}{c}2 \\
8.3\end{array}$ \\
\hline & $\begin{array}{l}\text { Scientific society/ } \\
\text { professional association }\end{array}$ & $\begin{array}{c}10 \\
100 \%\end{array}$ & $\begin{array}{c}8 \\
80.0 \%\end{array}$ & $\begin{array}{c}7 \\
70.0 \%\end{array}$ & $\begin{array}{c}6 \\
60.0 \%\end{array}$ & $\begin{array}{c}3 \\
30.0 \%\end{array}$ & $\begin{array}{c}3 \\
30.0 \%\end{array}$ \\
\hline \multirow{2}{*}{$\begin{array}{l}\text { Noninstitutional } \\
\text { publisher }\end{array}$} & Commercial publisher & $\begin{array}{c}14 \\
100 \%\end{array}$ & $\begin{array}{c}5 \\
35.7 \%\end{array}$ & $\begin{array}{c}3 \\
21.4 \%\end{array}$ & $\begin{array}{c}2 \\
14.3 \%\end{array}$ & $\begin{array}{c}0 \\
0.0 \%\end{array}$ & $\begin{array}{c}0 \\
0.0 \%\end{array}$ \\
\hline & Individuals & $\begin{array}{c}2 \\
100 \%\end{array}$ & $\begin{array}{c}2 \\
100 \%\end{array}$ & $\begin{array}{c}2 \\
100 \%\end{array}$ & $\begin{array}{c}1 \\
50.0 \%\end{array}$ & $\begin{array}{c}1 \\
50.0 \%\end{array}$ & $\begin{array}{c}1 \\
50.0 \%\end{array}$ \\
\hline \multirow{3}{*}{ Access model } & OA without APC & $\begin{array}{c}35 \\
100 \%\end{array}$ & $\begin{array}{c}29 \\
82.9 \%\end{array}$ & $\begin{array}{c}20 \\
57.1 \%\end{array}$ & $\begin{array}{c}12 \\
34.3 \%\end{array}$ & $\begin{array}{c}4 \\
11.4 \%\end{array}$ & $\begin{array}{c}5 \\
14.3 \%\end{array}$ \\
\hline & OA with APC & $\begin{array}{c}11 \\
100 \%\end{array}$ & $\begin{array}{c}2 \\
18.2 \%\end{array}$ & $\begin{array}{c}1 \\
9.1 \%\end{array}$ & $\begin{array}{c}1 \\
9.1 \%\end{array}$ & $\begin{array}{c}0 \\
0.0 \%\end{array}$ & $\begin{array}{c}0 \\
0.0 \%\end{array}$ \\
\hline & Not OA & $\begin{array}{c}4 \\
100 \%\end{array}$ & $\begin{array}{c}3 \\
75.0 \%\end{array}$ & $\begin{array}{c}2 \\
50.0 \%\end{array}$ & $\begin{array}{c}1 \\
25.0 \%\end{array}$ & $\begin{array}{c}1 \\
25.0 \%\end{array}$ & $\begin{array}{c}1 \\
25.0 \%\end{array}$ \\
\hline
\end{tabular}

During the content analysis, the reasons observed were grouped into five areas, based on the justification for their creation (Table 11). The first place was taken by reasons related to the field of public and institutional policies (36.0\%), which is logically closely related to that of the needs of the audiences $(32.0 \%)$, which occupied the second position. It should be noted that less than a third of the titles (28.0\%) present reasons based on thematic, disciplinary, or methodological scope. On the other hand, it is observed that the journals that have a more defined and limited thematic scope (in either some specific dimension or field of application) better justify their creation (Table 11).

Table 11. Areas in which reasons are presented to justify the creation of journals based on the type of publisher and the thematic scope in the ID field

\begin{tabular}{|c|c|c|c|c|c|c|c|c|c|}
\hline \multirow{3}{*}{$\mathrm{N}=50$} & & \multirow[b]{2}{*}{ 횽 } & \multirow{2}{*}{ 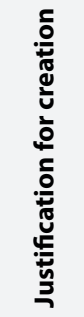 } & \multicolumn{5}{|c|}{ Scope in which the justification is presented } & \multirow{2}{*}{ 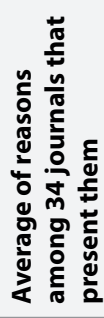 } \\
\hline & & & & 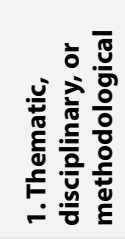 & 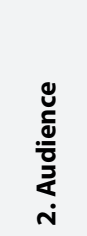 & 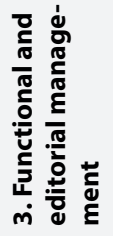 & 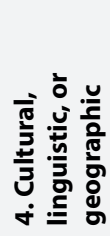 & 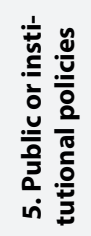 & \\
\hline & & $\begin{array}{c}50 \\
100 \%\end{array}$ & $\begin{array}{c}34 \\
68.0 \%\end{array}$ & $\begin{array}{c}14 \\
28.0 \%\end{array}$ & $\begin{array}{c}16 \\
32.0 \%\end{array}$ & $\begin{array}{c}4 \\
8.0 \%\end{array}$ & $\begin{array}{c}11 \\
22.0 \%\end{array}$ & $\begin{array}{c}18 \\
36.0 \%\end{array}$ & 2.1 \\
\hline \multirow{2}{*}{ Thematic scope } & General & $\begin{array}{c}32 \\
100 \%\end{array}$ & $\begin{array}{c}17 \\
53.1 \%\end{array}$ & $\begin{array}{c}2 \\
6.2 \%\end{array}$ & $\begin{array}{c}6 \\
18.7 \%\end{array}$ & $\begin{array}{c}1 \\
3.1 \%\end{array}$ & $\begin{array}{c}5 \\
15.6 \%\end{array}$ & $\begin{array}{c}10 \\
31.2 \%\end{array}$ & 1.6 \\
\hline & Specific & $\begin{array}{c}18 \\
100 \%\end{array}$ & $\begin{array}{c}17 \\
94.4 \%\end{array}$ & $\begin{array}{c}12 \\
66.7 \%\end{array}$ & $\begin{array}{c}10 \\
55.6 \%\end{array}$ & $\begin{array}{c}3 \\
16.7 \%\end{array}$ & $\begin{array}{c}6 \\
33.3 \%\end{array}$ & $\begin{array}{c}8 \\
44.4 \%\end{array}$ & 2.5 \\
\hline \multirow{2}{*}{ Of publisher } & Institutional & $\begin{array}{c}34 \\
100 \%\end{array}$ & $\begin{array}{c}27 \\
79.4 \%\end{array}$ & $\begin{array}{c}11 \\
32.4 \%\end{array}$ & $\begin{array}{c}12 \\
35.3 \%\end{array}$ & $\begin{array}{c}3 \\
8.8 \%\end{array}$ & $\begin{array}{c}10 \\
29.4 \%\end{array}$ & $\begin{array}{c}16 \\
47.1 \%\end{array}$ & 2.1 \\
\hline & Noninstitutional & $\begin{array}{c}16 \\
100 \%\end{array}$ & $\begin{array}{c}7 \\
43.8 \%\end{array}$ & $\begin{array}{c}3 \\
18.8 \%\end{array}$ & $\begin{array}{c}4 \\
25.0 \%\end{array}$ & $\begin{array}{c}1 \\
6.3 \%\end{array}$ & $\begin{array}{c}1 \\
6.3 \%\end{array}$ & $\begin{array}{c}2 \\
12.5 \%\end{array}$ & 1.7 \\
\hline
\end{tabular}

Among those that justify their creation, the average number of reasons stated is 2.1. If the thematic scope is taken into account, the results show that, in the case of general journals, it reached 1.6 per journal, while for those with a specific focus in terms of their subject or application environment, it is 2.5. Based on publisher type, the institutional ones present an average of 2.1 while the noninstitutional ones present 1.7. That is, although these 34 journals explicitly state the reasons for their creation, most do so with few reasons, and as we saw in Table 10, only in 5 cases were these reasons supported by arguments based on empirical data, such as bibliometric studies, surveys, analysis of the offering of the competition, etc. 
Delving into the detailed reasons codified in the content analysis of the 34 journals that justify their creation (Table 12), it can be seen that, by a long chalk, the main aim in creating a new journal is to "Enhance the projection and institutional recognition..." of the organization promoting the journal (47.1\%). It should also be noted that the second most common aim is to "Offer a vehicle to new voices close to academia but who are not part of it..." (26.5\%), in an attempt that is consistent with the introduction to research that is the aim of various educational programs at university centers that publish journals, or with the applied and professional nature of the knowledge generated in the ID area.

Many of the motives centered on the audience showed very low prevalence, as did those related to the need to accommodate thematic, disciplinary, or methodological evolution through the new titles. Given the strong presence of journals from emerging countries, the lack of justification discourse in the area of geographical, cultural, or linguistic motives is also surprising, with only 8 journals (23.5\%) explaining their desire to "Present a cultural, geographical, or linguistic perspective..."

Thus, considering the creation of journals in the ID area in recent years, a significant number of titles were created without clearly stating the purpose or objectives pursued, while among those that justify their creation, only a minority appeal to the needs of readers and authors or to the challenge of editorially channeling the epistemological and disciplinary transformation that is occurring in the ID area. Those two elements can be interpreted as the result of the proliferation of cloned generalist titles with a poorly defined profile, the absence of cooperative editorial projects to overcome institutional individualism, and last but not least, the appearance of OA publishers with dubious solvency whose business model is based on APCs.

Table 12. Ranking of explicit reasons given to justify the creation of journals

\begin{tabular}{|c|c|c|}
\hline \multirow{2}{*}{$\begin{array}{l}\text { Reason codes within one of the five areas considered } \\
\text { (Some journals may be classified in more than one code) }\end{array}$} & \multicolumn{2}{|c|}{$\begin{array}{l}\text { Journals } \\
\mathrm{N}=34\end{array}$} \\
\hline & $\mathbf{n}$ & $\%$ \\
\hline $\begin{array}{l}\text { 5b) Cultivate the projection and institutional recognition of universities, departments, new degrees, research centers, scien- } \\
\text { tific societies, or professional associations. }\end{array}$ & 16 & 47.1 \\
\hline $\begin{array}{l}2 \mathrm{~b}) \text { Offer a vehicle to new voices close to academia but not part of it: students, professionals who are starting out in the } \\
\text { profession, and experienced professionals who have never published. }\end{array}$ & 9 & 26.5 \\
\hline $\begin{array}{l}\text { 4a) Present a cultural, geographic, or linguistic perspective that contributes its own values in terms of topics, terminology, } \\
\text { and research perspectives. }\end{array}$ & 8 & 23.5 \\
\hline 1a) Provide emerging themes, social challenges, or lines of research with a dedicated space for scientific communication. & 6 & 17.6 \\
\hline 1b) Facilitate interdisciplinary communication between various fields of knowledge and methodological approaches. & 4 & 11.8 \\
\hline 1c) Allow alternative and critical discourses regarding the status quo of the disciplinary/thematic field. & 4 & 11.8 \\
\hline 1d) Offer an eminently practical approach from the professional context. & 4 & 11.8 \\
\hline 2c) Offer an instrument for professional renewal and debate among a target audience with specific needs in this regard. & 4 & 11.8 \\
\hline 4b) Promote professional and scientific cooperation between geographical areas with some cultural or political proximity. & 4 & 11.8 \\
\hline 2a) Respond to the growth in volume of researchers (or faculty) in a certain thematic, cultural, or geographical area. & 3 & 8.8 \\
\hline $\begin{array}{l}\text { 3b) Convert conference proceedings into journals to provide a higher-quality output avenue for works that, due to their } \\
\text { depth and value, should not be "buried" in conference proceedings organized by the scientific publishing community. }\end{array}$ & 3 & 8.8 \\
\hline $\begin{array}{l}\text { 5a) Contribute to a basic scientific communication system within the framework of the cultural, scientific, and economic } \\
\text { development policies of a country or region. }\end{array}$ & 2 & 5.9 \\
\hline 3a) Offer an OA alternative to other subscription journals with a similar scope and audience. & 1 & 2.9 \\
\hline
\end{tabular}

\subsubsection{Title changes}

Journals that are transformed by a change of title do not clearly justify this process either. Only the 5 journals that published an editorial article present some kind of justification. Among these 5 journals, three of them are generalist in terms of both subject matter and application context: one is a generalist in the field of archives, while another is specialized in technology and technical documentary processes addressing all types of application contexts. Thus, considering the motives related to disciplinary or methodological thematic scope, the 5 journals explain that, by changing their title, they want to capture the broadening of the thematic scope, while none of them explicitly desire to narrow it down or define it better. A total of 4 aim to respond to emerging technologies or the digital transformation of the ID area; and finally, 2 seek to open up to work that is interdisciplinary or multidisciplinary, or directly from other disciplines. Only 2 provide reasons based on the scope of their audience, in the sense of expanding the range of readers or authors. Finally, 2 of them present reasons from the area of institutional policies, since these journals are managed by a commercial publisher and change their title as a result of a reorganization within the associations that promote them. Furthermore, only in 1 case is empirical evidence provided to support the justification, and in only one other case is the organic decision-making process explained.

The breadth in themes and approaches, which could even sometimes be described as dispersion, has been reinforced in recent years by an opening up that dilutes disciplinary borders 
It is surprising that publishers with a consolidated track record document the changes they have made in such an unreliable way, in either the last issue of the series that ends the previous title or the first of the new series. This behavior is emphasized by the publisher Emerald, which with 8 publications is the publisher involved in $66.7 \%$ of the cases of title change, but only justifies this process in 2 of them.

\section{Conclusions}

The creation and transformation of titles in the ID area in the analyzed period provides more doubts than insights, in terms of both the way and depth with which publishers justify such editorial initiatives. Taken together, the analyzed titles do not offer a lively and innovative image of the area, as evidenced by the recurring commitment to general and broad-spectrum titles with little differentiation.

From a methodological point of view, this work aimed to evaluate the moment of creation of a journal and the way in which the publishers justify their creation via presentation pieces. This approach prevents us from studying reasons that are not stated, for which it would be necessary to obtain information directly through interactions with the publishers, but it does allow a significant degree of objectivity. In any case, the lack of justification texts or their low quality provides a first-rate indication to support the supposition that many journals are created more as a response to the needs of those who promote them than as an instrument to serve an audience. Having established the limitations and potential of the method applied herein, we answer the following research questions asked in this work:

\section{RQ1. What is the profile of the new journals and title changes?}

- Among the newly created titles, there is a significant presence of university publishers from countries where the higher education system is expanding.

These are areas in which the number of people linked to the ID area within the university system is growing, so that journals seek a space for scientific discussion in their local language and to allow the consideration of issues that are important in their context. Above all, this is about obtaining prestige and the rewards of being part of a project of creating a journal.

- The penetration of open access is a principal factor explaining the evolution of the creation of titles.

Of the titles created, $92.0 \%$ are OA, mainly by publishers from the institutional and academic fields, but with a significant presence of native-digital commercial publishers, which generally contribute an offering that is financially unsound and unreliable.

- Title changes were identified only in the field of commercial publishers with a proven tradition in the ID area, which, on the other hand, only registered one newly created title in the analyzed period.

This situation indicates a capacity for analysis and adaptation to change within editorial continuity, which does not seem to be present within the noncommercial offering of titles in the ID area.

- The presence of title mergers is insignificant.

In the analyzed period, only one merger was identified, occurring between two journals of a professional association to give rise to a title managed by a commercial editor. Mergers as a way to search for synergies in the editorial process, brand creation, and economies of scale have not been the response of publishers in the ID area to an environment in the communication ecosystem that presents significant sustainability challenges for journals in this field. This absence of mergers is striking against a background in which many quasi-clone journals are seen nationwide, having a low publication frequency and a very limited volume of articles per year.

\section{RQ2. What are the characteristics of the journals in terms of their survival, volume of articles published,} inclusion in databases, or citations received?

- Newly created journals have a very low presence in databases and receive very few citations.

This highlights the difficulty they have in obtaining external recognition, despite the fact that all of them already have a history of more than one year. Furthermore, since a large majority of the journals are open access, the low presence observed in DOAJ casts additional doubts on their merit as useful instruments for authors. On the other hand, given that the source of the citations is Google Scholar, the low level of citations observed indicates that a good part of the journals have no impact either in their immediate environment or among the authors who publish in those journals.

- Newly created journals publish few articles per year or irregularly report metadata to Crossref.

Although a small number of articles per year may be synonymous with a highly selective policy of accepting original pieces, this is not usually the case for journals with little track record and recognition. The low volume of article production, or metadata management towards Crossref, along with other elements of journal operation, may be associated with unprofessional editorial projects. 
RQ3. What is the orientation of the journals in terms of the scope they give to the discipline, its methods, and its themes?

- General journals and openness to other areas beyond ID prevail.

Both in the creation of new journals and in the changes of title, there are very few titles whose existence is justified by offering a specialization in a specific field within the ID area. In addition, in a large number of cases, the way in which the scope of the journal is presented and the invitation to publish are oriented so as to not restrict the manuscripts to authors of the traditional culture of the ID area.

- The editorial texts used to present the journals generally provide few arguments related to the evolution of the ID area.

Among the 62 journals analyzed, only 19 (30.6\%) present reasons based on the thematic, disciplinary, or methodological scope, which indicates a lack of reflection and positioning of the editors on the scope of the ID area to which their journal will be dedicated. This finding is quite surprising given that many authors have wondered in recent years about the scope of the ID field and their own disciplinary identity, something that is reflected in multiple processes of organic convergence of units in the ID area with other departments and faculties in the university environment.

\section{RQ4. How do their promoters justify the creation of new journals or the change of title of existing journals?}

- In a high percentage of cases, the creation or change of title of the journals is not justified; when it is done, the argumentation is generally poor.

Although these findings may be considered to limit the study of the process of creation or transformation of journals, we believe that they provide highly valuable evidence when it comes to portraying the vitality of the area and the quality of the editorial projects generated.

- The lack of justification is particularly stark in the case of the analyzed titles that have other characteristics suggesting their unreliability.

The absence of well-written editorial presentation texts, or the weakness of the arguments used to justify the appearance of the journal, when they appear in titles that promise quick publication of manuscripts and that present elements mentioned by the Committee on Publication Ethics (COPE) in its proposed definition for "predatory journals" (COPE, 2019), allows us to affirm that this problem is present in journals in the ID area, despite being a small market. In view of the data obtained, OA publishers that charge an APC and that are not linked to an academic institution or association in the LIS field, or that do not come from publishers with a recognized track record, offer the worst guarantees, considering their characteristics and performance during the first years of life analyzed.

- The number of cases in which some information is offered on the decision-making process for the creation or change of title, as well as the data and evidence taken into account, is revealing.

In the case of university presses, this lack of transparency prevents the identification in many cases of the extent to which the initiative to create a journal is basically the result of the personal and individual will of a small core of promoters, or if it has real support from the university that is mentioned as the publisher, beyond the hosting of the journal in the portal of the institution.

- Less than a third of the newly created journals present reasons based on thematic, disciplinary, or methodological scope to justify their appearance.

The most prevalent reasons presented are related to the field of public and institutional policies, among which the reason most often seen is that of "Enhancing the projection and institutional recognition of universities, departments, new degrees, centers of research, scientific societies, or professional associations."

\section{Notes}

1. Search performed on 21 December 2019:

https://www.google.com/search?q=\%22do+we+need+a+new+journal\%22

Similar phrases in Spanish or Portuguese, for example, do not return a significant number of results. The type of articles that can be found in English range from editorial pieces within the journal itself, where the raison d'être is presented and justified (Rosen; Israeli, 2012; Arasa, 2016), to studies published in other journals in which the opportunity for the new launch is justified based on data (Lichstein, 2003).

2. The pioneering work "Why are new journals founded?" (Rowland, 1981), developed under the auspices of the Royal Society of London, has received very few citations, and most are indirectly related to the research problem posed. A search for empirical work equivalent to Rowland's yielded negative results.

3. Given the great variability observed in the denomination of the disciplinary field traditionally called "Library Science and Documentation", we chose to use the term "Information and Documentation," in line with the name used by the International Organization for Standardization (ISO) to group the standards managed by Technical Committee 46 "Information and Documentation."

https://www.iso.org/committee/48750.html 


\section{References}

Aharony, Noa (2012). "Library and information science research areas: a content analysis of articles from the top 10 journals 2007-8". Journal of librarianship and information science, v. 44, n. 1, pp. 27-35. https://doi.org/10.1177/0961000611424819

Aparicio, Alicia; Banzato, Guillermo; Liberatore, Gustavo (2016). Manual de gestión editorial de revistas científicas de ciencias sociales y humanas: buenas prácticas y criterios de calidad. Buenos Aires: Clacso. ISBN: 9789877222135

Arasa, Daniel (2016). "Why a new journal?". Church, communication and culture, v. 1, n. 1, pp. 1-6. https://doi.org/10.1080/23753234.2016.1179423

Bailey, Janet D. (1989). “New journal decision making”. College \& research libraries, v. 50, n. 3, pp. 354-359. https://doi.org/10.5860/crl_50_03_354

Baue, Arthur E. (2002). "New journals, new societies, more meetings - Do we need them all?". Archives of surgery, v. 137, n. 12, pp. 1413-1416. https://doi.org/10.1001/archsurg.137.12.1413

Berger, Monica; Cirasella, Jill (2015). “Beyond Beall's List”. College \& research libraries news, v. 76, n. 3, pp. $132-135$. https://doi.org/10.5860/crln.76.3.9277

Bernal, John-Desmond (1939). The social function of science. London: George Routledge \& Sons. https://archive.org/details/in.ernet.dli.2015.218588

Binfield, Peter (2014). "Novel scholarly journal concepts". In: Bartling, S.; Friesike, S. (eds.) Opening science. Springer, Cham, pp. 155-163.

https://doi.org/10.1007/978-3-319-00026-8_10

Binfield, Peter; Rolnik, Zachary; Brown, Cindy; Cole, Kerry (2008). "Academic journal publishing”. Serials librarian, v. 54, n. 1-2, pp. 141-153.

https://doi.org/10.1080/03615260801973992

Björk, Bo-Christer; Solomon, David (2015). “Article processing charges in OA journals: relationship between price and quality". Scientometrics, v. 103, n. 2, pp. 373-385.

https://doi.org/10.1007/s11192-015-1556-z

Chang, Yu-Wei (2018). "Examining interdisciplinarity of library and information science (LIS) based on LIS articles contributed by non-LIS authors". Scientometrics, v. 116, n. 3, pp. 1589-1613.

https://doi.org/10.1007/s11192-018-2822-7

Chavarro, Diego; Tang, Puay; Ràfols, Ismael (2017). "Why researchers publish in non-mainstream journals: Training, knowledge bridging, and gap filling". Research policy, v. 46, n. 9, pp. 1666-1680.

https://doi.org/10.1016/j.respol.2017.08.002

Chen, Chuanfu; Li, Qiao; Deng, Zhiqing; Chiu, Kuei; Wang, Ping (2018). "The preferences of Chinese LIS journal articles in citing works outside the discipline". Journal of documentation, v. 74, n. 1, pp. 99-118.

https://doi.org/10.1108/JD-04-2017-0057

Chu, Heting (2006). "Curricula of LIS programs in the USA: A content analysis". In: Proceedings of the Asia-Pacific conference on library \& information education \& practice 2006, pp. 328-337.

https://repository.arizona.edu/handle/10150/105144

Cope, Bill; Kalantzis, Mary (2014). "Changing knowledge ecologies and the transformation of the scholarly journal”. In: The future of the academic journal. Oxford: Elsevier, pp. 9-83.

https://doi.org/10.1533/9781780634647.9

COPE Council (2019). COPE discussion document: predatory publishing, Committee on Publication Ethics (COPE). https://doi.org/10.24318/cope.2019.3.6

COPE Council (2020). "Committee on Publication Ethics guidelines". https://publicationethics.org/guidance/Guidelines

Coulter, Gerry (2010). "Launching (and sustaining) a scholarly journal on the Internet: the International Journal of Baudrillard studies". The journal of electronic publishing, v. 13, n. 1, pp. 1-8.

https://doi.org/10.3998/3336451.0013.104

Cox, Brian (2002). "The Pergamon phenomenon 1951-1991: Robert Maxwell and scientific publishing". Learned publishing, v. 15, n. 4, pp. 273-278.

https://doi.org/10.1087/095315102760319233 
Crow, Raym; Gallagher, Richard; Naim, Kamran (2019). "Subscribe to open: a practical approach for converting subscription journals to open access". Learned publishing, September, pp. 181-185.

https://doi.org/10.1002/leap.1262

Delgado-López-Cózar, Emilio (2001). “Las revistas españolas de ciencias de la documentación: productos manifiestamente mejorables". El profesional de la información, v. 10, n. 12, pp. 46-56.

http://www.elprofesionaldelainformacion.com/contenidos/2001/diciembre/10.pdf

DORA (2012). "San Francisco Declaration on Research Assessment (DORA)".

https://sfdora.org/read

Egghe, Leo (2007). "Welcome to the Journal of informetrics". Journal of informetrics, v. 1, n. 1, p. 1.

https://doi.org/10.1016/j.joi.2006.09.003

Esposito, Joseph (2014). "The size of the open access market". The scholarly kitchen, Oct. 29.

https://scholarlykitchen.sspnet.org/2014/10/29/the-size-of-the-open-access-market

Gu, Xin; Blackmore, Karen L. (2016). “Recent trends in academic journal growth”. Scientometrics, v. 108, n. 2, pp. 693716.

https://doi.org/10.1007/s11192-016-1985-3

Guallar, Javier; Ferran-Ferrer, Núria; Abadal, Ernest; Server, Adán (2017). "Revistas científicas españolas de información y documentación: análisis temático y metodológico". El profesional de la información, v. 26, n. 5, p. 947.

https://doi.org/10.3145/epi.2017.sep.16

Guédon, Jean-Claude (2014). "Sustaining the 'Great conversation': the future of scholarly and scientific journals”. In: The future of the academic journal. Oxford: Elsevier, pp. 85-112.

https://doi.org/10.1533/9781780634647.85

Guédon, Jean-Claude (dir.) (2019). Future of scholarly publishing and scholarly communication: report of the expert group to the European Commission. European Commission, Luxembourg: Publications Office of the European Union. ISBN: 9789279972386

https://doi.org/10.2777/836532

Hartley, John; Potts, Jason; Montgomery, Lucy; Rennie, Ellie; Neylon, Cameron (2019). "Do we need to move from communication technology to user community? A new economic model of the journal as a club". Learned publishing, $\mathrm{v}$. 32, n. 1, pp. 27-35.

https://doi.org/10.1002/leap.1228

Haynes, John (1999). "New journal of physics: a web-based and author-funded journal”. Learned publishing, v. 12, n. 4, pp. 265-269.

https://doi.org/10.1087/09531519950145661

Hicks, Diana; Wouters, Paul; Waltman, Ludo; De-Rijcke, Sarah; Ràfols, Ismael (2015). "Bibliometrics: The Leiden manifesto for research metrics". Nature, v. 520, n. 7548, pp. 429-431.

https://doi.org/10.1038/520429a

14OC. "Initiative for Open Citations".

https://i4oc.org/

ISO 8 (2019). ISO 8:2019 (E). Information and documentation - Presentation and identification of periodicals, Geneva: ISO. ISBN: 2831886376

Johnson, Melissa E.; Putnam-Davis, Jennifer; Bandy, Sandra (2019). "Bridging the gap: sustaining publication of a newly created undergraduate research journal". The serials librarian, pp. 1-6.

https://doi.org/10.1080/0361526X.2020.1696622

Johnson, Rob; Mabe, Anthony; Mabe, Michael (2018). The STM report: an overview of scientific and scholarly publishing: 1968-2018, celebrating the 50 th anniversary of STM. The Hague: International Association of Scientific, Technical and Medical Publishers.

https://www.stm-assoc.org/2018_10_04_STM_Report_2018.pdf

Kim, Lanu; Portenoy, Jason H.; West, Jevin D.; Stovel, Katherine W. (2019). "Scientific journals still matter in the era of academic search engines and preprint archives". Journal of the Association for Information Science and Technology, September, asi.24326. https://doi.org/10.1002/asi.24326

Kratochvíl, Jiří; PIch, Lukáš; Sebera, Martin; Koritáková, Eva (2020). "Evaluation of untrustworthy journals: Transition from formal criteria to a complex view". Learned publishing, v. 2008, March, pp. 1-15.

https://doi.org/10.1002/leap.1299 
Larivière, Vincent; Haustein, Stefanie; Mongeon, Philippe (2015). "The oligopoly of academic publishers in the digital era". PloS one, v. 10, n. 6, e0127502.

https://doi.org/10.1371/journal.pone.0127502

Lichstein, Kenneth L. (2003). "Is there a need for another sleep journal?”. Journal of psychosomatic research, v. 54, n. 1, pp. 93-96. https://doi.org/10.1016/S0022-3999(02)00541-X

Lin, Songqing (2013). "How the approval system affects Chinese scientific journals". Learned publishing, v. 26, n. 4, pp. 303-309.

https://doi.org/10.1087/201304010

Lyons, Scott (2011). "Case study on the development of the International journal of exercise science”. Berkeley Electronic Press Case Studies Collection http://works.bepress.com/scott_lyons/5

Mabe, Michael; Amin, Mayur (2001). "Growth dynamics of scholarly and scientific journals". Scientometrics, v. 51, n. 1, pp. 147-162.

https://doi.org/10.1023/A:1010520913124

Martín-Martín, Alberto; Orduña-Malea, Enrique; Thelwall, Mike; Delgado-López-Cózar, Emilio (2018). “Google Scholar, Web of Science, and Scopus: A systematic comparison of citations in 252 subject categories". Journal of informetrics, $\mathrm{v}$. 12, n. 4.

https://doi.org/10.1016/j.joi.2018.09.002

Marušić, Matko; Marušić, Ana; King, Ruth (2013). “Establishing a new journal”. In: Science editors' handbook. Redruth: European Association of Science Editors, pp. 1-4. ISBN: 9780905988115

Meneghini, Rogerio (2012). "Emerging journals: the benefits of and challenges for publishing scientific journals in and by emerging countries". EMBO reports, v. 13, n. 2, pp. 106-108.

https://doi.org/10.1038/embor.2011.252

Neuendorf, Kimberly A. (2002). The content analysis guidebook. Thousand Oaks (Calif.): Sage Publications. ISBN: 0761919783

https://academic.csuohio.edu/kneuendorf/SkalskiVitae/SkalskiNeuendorfCajigas17.pdf

Ollé-Castellà, Candela; López-Borrull, Alexandre; Abadal, Ernest (2016). "The challenges facing library and information science journals: editors' opinions". Learned publishing, v. 29, n. 2, pp. 89-94.

https://doi.org/10.1002/leap.1016

Piwowar, Heather; Priem, Jason; Orr, Richard (2019). "The future of OA: a large-scale analysis projecting Open Access publication and readership [preprint]". bioRxiv, 795310.

https://doi.org/10.1101/795310

Price, Derek J. de Solla (1961). Science since Babylon, New Haven: Yale University Press, ISBN: 9780300017984

Regier, Willis-Goth (2005). "Starting and killing -or reviving- journals". Journal of scholarly publishing, v. 37, n. 1, pp. 2-8. https://doi.org/10.1353/scp.2005.0030

Repiso, Rafael; Orduña-Malea, Enrique; Aguaded, Ignacio (2019). "Revistas científicas editadas por universidades en Web of Science: características y contribución a la marca universidad”. El profesional de la información, v. 28, n. 4, pp. $1-10$.

https://doi.org/10.3145/epi.2019.jul.05

Rosen, Bruce; Israeli, Avi (2012). "Launching the Israel journal of health policy research: Why a new journal? Why now? Why open access?". Israel journal of health policy research, v. 1, n. 1, pp. 2-5.

https://doi.org/10.1186/2045-4015-1-1

Rowland, J.F.B. (1981). "Why are new journals founded?". Journal of documentation, v. 37, n. 1, pp. 36-40. https://doi.org/10.1108/eb026705

Suber, Peter (2009). "Knowledge as a public good". Sparc open access newsletter, November $2^{\text {th }}$. http://nrs.harvard.edu/urn-3:HUL.InstRepos:4391171

Singh-Chawla, Dalmeet (2019). “Open-access row prompts editorial board of Elsevier journal to resign”. Nature. News, January, $14^{\text {th }}$.

https://doi.org/10.1038/d41586-019-00135-8

Smart, Pipa (2018). Handbook for journal editors. Oxford: Inasp.

https://www.inasp.info/editorshandbook 
Solomon, David J.; Björk, Bo-Christer (2012). "A study of open access journals using article processing charges". Journal of the American Society for Information Science and Technology, v. 63, n. 8, pp. 1485-1495. https://doi.org/10.1002/asi.22673

Stranack, Kevin (2008). Starting a new scholary journal in Africa. Vancouver: Public Knowledge Project (PKP). https://pkp.sfu.ca/files/AfricaNewJournal.pdf

Sugimoto, Cassidy R. (2019). "The International Society for Scientometrics and Informetrics ends support for Journal of Informetrics, launches new open-access journal Quantitative Science Studies". ISSI blog.

http://issi-society.org/blog/posts/2019/january/the-international-society-for-scientometrics-and-informetrics-endssupport-for-journal-of-informetrics-launches-new-open-access-journal-quantitative-science-studies

Tuomaala, Otto; Järvelin, Kalervo; Vakkari, Pertti (2014). “Evolution of library and information science, 1965-2005: Content analysis of journal articles". Journal of the Association for Information Science and Technology, v. 65, n. 7, pp. 1446-1462.

https://doi.org/10.1002/asi.23034

Urbano, Cristóbal; Ardanuy, Jordi (2020). “Cross-disciplinary collaboration versus coexistence in LIS serials: analysis of authorship affiliations in four European countries". Scientometrics.

https://doi.org/10.1007/s11192-020-03471-z

Van-Raan, Anthony (2019). "Measuring science: basic principles and application of advanced bibliometrics". In: Springer handbook of science and technology indicators. Cham: Springer, pp. 237-280.

https://doi.org/10.1007/978-3-030-02511-3_10

Velterop, Jan (2018). "Plan S and article processing charges (APCS)". SciELO in perspective, Nov. 27, pp. 1-5. https://blog.scielo.org/en/2018/11/27/plan-s-and-article-processing-charges-apcs

Whitley, Richard (1982). "The establishment and structure of the sciences as reputational organizations". In: Scientific establishments and hierarchies. Dordrecht: Springer, pp. 313-357.

https://doi.org/10.1007/978-94-009-7729-7_12

Willinsky, John; Moorhead, Laura (2014). "How the rise of open access is altering journal publishing". In: The future of the academic journal. Oxford: Elsevier, pp. 195-222.

https://doi.org/10.1533/9781780634647.195

Ziman, John-Michael (1980). "The proliferation of scientific literature: a natural process". Science, v. 208, n. 4442, pp. 369-371.

https://doi.org/10.1126/science. 7367863

Zins, Chaim (2007). "Conceptions of information science". Journal of the American Society for Information Science and Technology, v. 58, n. 3, pp. 335-350.

https://doi.org/10.1002/asi.20507

\section{Supplementary material}

\section{Data file}

The research data file in Excel format is available on:

https://doi.org/10.6084/m9.figshare.12639692

Please cite this data set as:

Urbano, Cristóbal; Schwarz-Rodrigues, Rosângela; Somoza-Fernández, Marta; Rodríguez-Gairín, Josep-Manuel (2020). Why are new journals created? An international analysis of information and documentation titles (20132018) [Data set]. Figshare. Dataset.

https://doi.org/10.6084/m9.figshare.12639692

Page 1. Data of the 62 titles analyzed (2013-2018).

Page 2. Data of the 68 titles from the previous period (2007-2012).

Page 3. Content analysis (CA) questionnaire.

Page 4. CA motive codes.

Page 5. Thematic classification. 